\title{
Plant growth and quality of cucumber grafted with Lagenaria siceraria in soil infested with nematodes
}

\author{
Ángel Manuel Suárez-Hernández¹, Onécimo Grimaldo-Juárez²*, Carlos Ceceña-Durán², \\ Isidro Bazante-González', Fidel Núñez-Ramirez², Daniel González-Mendoza²
}

${ }^{1}$ Faculty of Engineering and Business San Quintin, Autonomous University of Baja California, Baja California, Mexico. ${ }^{2}$ Institute of Agricultural Sciences, Autonomous University of Baja California, Baja California, Mexico

\section{A B S T R A C T}

Grafting cucurbitaceous crops is an alternative for protection of plants in production systems with biotic or abiotic stress. The grafting cucumber improves the plant growth and development under adverse conditions, such as drought, high salt concentration and soil-borne pathogens. Lagenaria siceraria is a species with potential rootstocks in cucumber. Mexican L. siceraria accessions are less susceptible to damage caused by Meloidogyne incognita. The aim of this study was to evaluate two Mexican L. siceraria accessions (Lag 48 and Lag 53) and Forticuke F1 (Numhems ${ }^{\circledR}$ ) as rootstocks on plant growth and fruit quality of cucumber in soil infested with root-knot nematodes. Plant ungrafted was used as control. The results show that rootstocks increased plant height, leaves number and leaf area. Forticuke F1 and Lag 53 had a greater response than ungrafted plant. The grafting increased fruit weight in $25.3 \%, 15.2 \%$ and $14.6 \%$ with Forticuke F1, Lag 53 and Lag 48, respectively. Internal firmness of the fruits increased by $56.4 \%$ in Forticuke $\mathrm{F} 1,12.6 \%$ in Lag 53 and $2.2 \%$ in Lag 48 with respect to ungrafted plants. Length, diameter, external firmness and Brix degrees of fruit were not modified by rootstock effect. The use of $L$. siceraria as rootstock is an alternative to improvement plant growth and fruit quality of cucumber in soil infested with root-knot nematodes.

Keywords: Cucumis sativus; graft; Meloidogyne incognita; root-knot nematodes

\section{INTRODUCTION}

One of the limiting factors in cucumber production system is incidence of nematodes that affect normal plants development (Amin and Mona, 2014). Root-knot nematodes reduce water and nutrients transportation in plants (Navarrete et al., 2018). Among root-knot nematodes of greater agricultural importance are $M$. incognita, M. javanica, M. arenaria, and $M$. hapla, species distributed individual or combined in different agricultural regions of Mexico, with $M$. incognita being predominant species in warm areas (Del Prado-Vera et al., 2001).

The strategy used by farmers to counteract nematodes presence is application of organophosphates and carbamates pesticides, as well as methyl bromide (Jones et al., 2016). These products are considered highly toxic to humans and environment, reason why its use has been restricted (Gupta et al., 2017). The forgoing has led development of ecological alternatives such as crop rotation, cover crops, resistant varieties, biological control and grafted plants (Ban et al., 2014; Singh and Phulera, 2015).

Some species tolerant to $M$. incognita are of genus Cucurbita, Citrullus and Cucumis (Punithaveni et al., 2015; Thangamani et al., 2018). The species Lagenaria. siceraria are classified as susceptible. However, L. siceraria used as rootstock in root-knot nematode-susceptible cv. Hesham presents moderate resistance (El-Wanis et al., 2013). Cucumber Lama hybrid grafted onto three rootstocks of L. siceraria (Emphasis, PI 534556 and Egyptian local variety) increments plant height, internodes length, leaves number and leaf area (El Eslamboly and Deabes, 2014). While in Cucumber cv. Adrian grafted onto three commercial rootstocks (Emphasis, S-1 and Friend) reduces leaves number, and fruit characters such as weight, diameter, degrees brix and pH are not modify (Ban et al., 2014). However, there are no studies on $L$. siceraria accessions as rootstock in soils infested with root-knot nematodes.

\footnotetext{
*Correspondence author: Onécimo Grimaldo-Juárez, Institute of Agricultural Sciences, Autonomous University of Baja California, Baja California, Mexico. Tel.: +526861738871. E-mail: onecimo.grimaldo@uabc.edu.mx
}

Received: 24 September 2020;

Accepted: 30 December 2020 
Recent studies have shown the benefits of using L. siceraria as rootstock in cucumber under other environments. L. siceraria as rootstock in hybrid cucumber cv. Kalaam F1 under non-stressful environment promotes higher plant growth and fruit quality, mainly in parameters such as plant height, leaf area, fruit weight and yield (Noor et al., 2019). Under saline conditions, cucumber plants grafted increase fruits number and reduce non-marketable percentage (Huang et al., 2009). Tolerance to salinity is result of morphological and physiological changes in plant (Elsheery et al., 2020).

A morphological study of accessions diversity in different regions of Mexico indicates that fruits vary in size and shape (Grimaldo et al., 2018). Mexican L. siceraria accessions used as rootstock have positive effects on fruit quality in watermelon (Suárez et al., 2017a, b). Another study related with Mexican L. siceraria accessins, indicates that are less susceptible to root-knot nematodes compared with other regions of the world (Levi et al., 2009). However, there is no evidence of studies related to nematodes tolerance of Mexican L. siceraria landraces on plant growth and fruit quality of cucumber. Therefore, our objective of this study was to evaluate the effect of two Mexican L. siceraria accessions (Lag 53 and Lag 48) and Forticuke F1 (commercial rootstock) on plant growth and fruit quality of cucumber in soil infested with rootknot nematodes.

\section{MATERIAL AND METHODS}

The experiment was carried out in a low-tech greenhouse covered with polycarbonate roof during spring 2019 at Institute of Agricultural Sciences of Autonomous University of Baja California, Mexico $\left(32^{\circ} 24^{\prime} 19^{\prime \prime} \mathrm{N}, 115^{\circ}\right.$ $11^{\prime} 48^{\prime \prime} \mathrm{W}$, and at an elevation of $14 \mathrm{~m}$ ). The climate of the region is very dry with $13.6^{\circ} \mathrm{C}$ and $31.7^{\circ} \mathrm{C}$ minimum and maximum annual temperature, respectively. Annual precipitation is $10 \mathrm{~mm}$. The temperature inside the greenhouse oscillated between $20^{\circ} \mathrm{C}$ to $40^{\circ} \mathrm{C}$ from April to June 2019 (Fig. 1), presenting higher temperatures in May and June. Relative humidity during the experiment was 20 to $90 \%$ (Fig. 2).

Centenario cucumber variety was used as scion, which was grafted in three roostoocks: the commercial hybrid Forticuke F1 (Numhems ${ }^{\circledR}$ ) and two Mexican L. siceraria accessions (Lag 48 and Lag 53). Centenario ungrafted was included as control. The cleft grafting technique was used (Maroto et al., 2002). The experimental unit consisted of 15 plants. A randomized block design with three replications was used.

Grafted and ungrafted seedlings were established at 21 days after grafting in polyethylene bags with capacity of $10 \mathrm{~L}$. The bags contained $5 \mathrm{~kg}$ of contaminated soil with M. incognita. Nematological analysis of a composite sample showed a density of 45 second-stage juveniles per 100 grams of soil. The texture was sandy its chemical properties were showed in Table 1.

The water and nutrients were supplied by drip irrigation. Water contained EC $1.1 \mathrm{dS} \mathrm{m}^{-1}$ and $\mathrm{pH}$ 8.3. The nutrient solution was applied 7 days after planting. The nutrient contents were: 8.0 meq K $\mathrm{K}^{-1}, 8.0$ meq Ca ${ }^{+2} \mathrm{~L}^{-1}, 1.25 \mathrm{meq}$ $\mathrm{NH}_{4}^{+} \mathrm{L}^{-1}, 16.0$ meq $\mathrm{NO}_{3}^{-} \mathrm{L}^{-1}, 2.7 \mathrm{meq} \mathrm{SO}_{4}^{-2} \mathrm{~L}^{-1}$ and 1.25 meq $\mathrm{H}_{2} \mathrm{PO}_{4}^{-} \mathrm{L}^{-1}$ (Cadahia, 2005).

The variables evaluated were of plant growth and fruit quality. The plant growth was quantified two months after it was established considering height $(\mathrm{cm})$, internode distance $(\mathrm{cm})$, leaves number and leaf area $\left(\mathrm{cm}^{2}\right)$. Leaf area was determined using an LI-3100C Area Meter (LICOR Inc. USA). Fruit quality was evaluated on ten fruits considered at random from each experimental unit in the first harvest. Cucumber was harvested in the morning

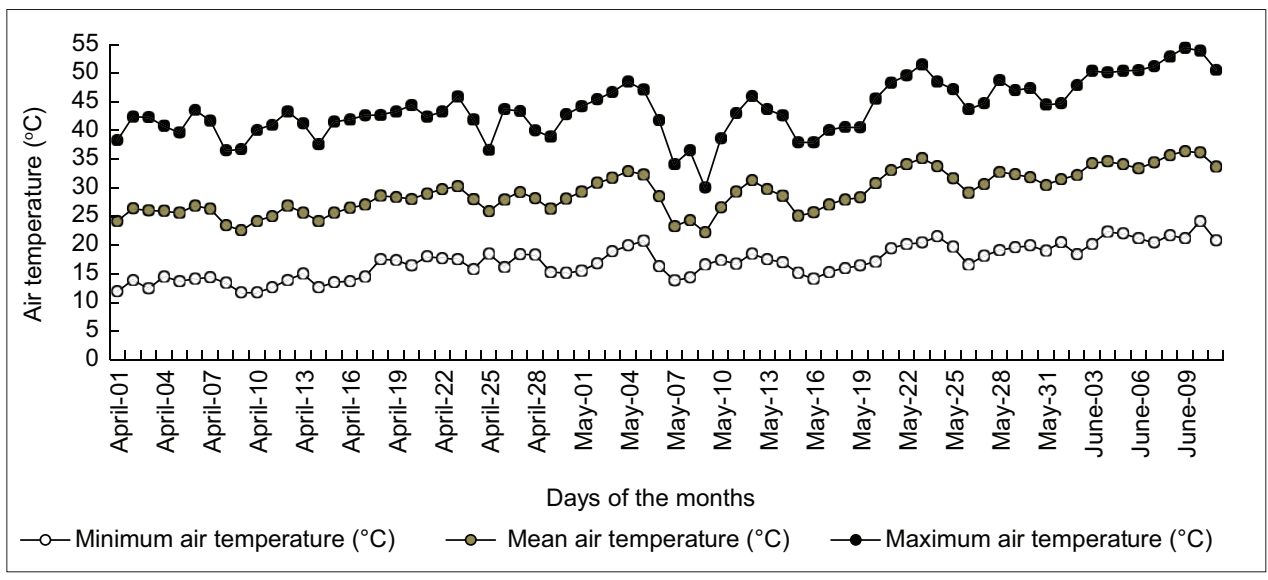

Fig 1. Minimum, mean and maximum daily air temperature during crop development inside the greenhouse in April to June 2019. 


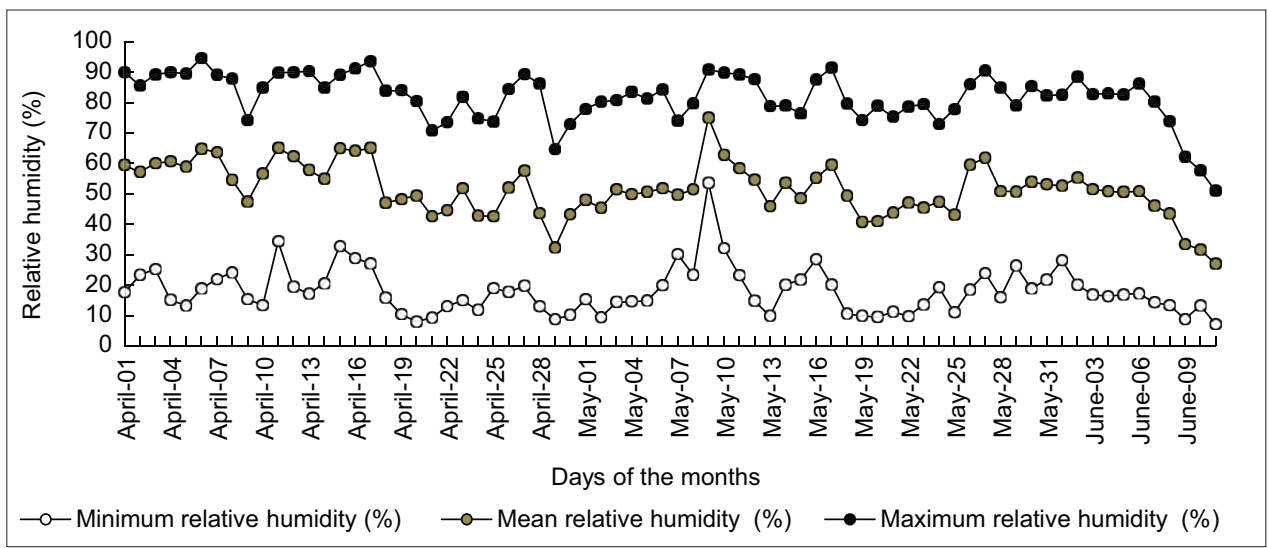

Fig 2. Minimum, mean and maximum daily relative humidity during crop development inside the greenhouse in April to June 2019.

Table 1: Soil fertility analysis and concentrations of specific ions in the extract

\begin{tabular}{|c|c|c|c|c|c|c|c|c|c|c|}
\hline \multicolumn{11}{|c|}{ Analysis of the soil } \\
\hline MO & $\mathrm{CO}$ & $\mathrm{N}-\mathrm{NO}_{3}$ & $\mathrm{P}_{-} \mathrm{PO}_{4}$ & K int, & Ca int. & Mg int. & $\mathrm{Fe}$ & $\mathrm{Zn}$ & Mn & $\mathrm{Cu}$ \\
\hline \multicolumn{11}{|c|}{ ppm } \\
\hline 10200 & 8500 & 14.4 & 10.9 & 550 & 1100 & 450 & 4 & 3 & 1.9 & 0.82 \\
\hline \multicolumn{11}{|c|}{ Concentrations of specific ions in the extract } \\
\hline EC & pH & SST & $\mathrm{Ca}^{2+}$ & $\mathrm{Mg}^{2+}$ & $\mathbf{K}^{+}$ & $\mathrm{Na}^{+}$ & $\mathrm{CO}_{3}^{2-}$ & $\mathrm{HCO}_{3}$ & $\mathrm{Cl}^{-}$ & SAR \\
\hline dS $\mathbf{~ m}^{-1}$ & \multicolumn{10}{|c|}{ ppm } \\
\hline 2.76 & 7.2 & 1766 & 239 & 76 & 30 & 172 & 0.00 & 174 & 404 & 2.5 \\
\hline
\end{tabular}

MO: organic matter; CO: organic carbon; K int.: exchangeable potassium; Ca int.: exchangeable calcium; Mg int.: exchangeable magnesium; SST: total soluble salts; SAR: sodium absorption ratio

according to specifications of the National Quality Standard (MMXFF023, 1983). Variables evaluated were weight $(\mathrm{g})$, length $(\mathrm{cm})$, diameter $(\mathrm{mm})$. Firmness was quantified with a Chatilllon DFE-100 digital force gauge (AETEK Inc, USA), considering external firmness $(\mathrm{N})$ as average value of three punctures in the whole fruit and internal firmness $(\mathrm{N})$ as average value of three punctures in fruit mesocarp. Content of soluble solids (Brix) was determined with a Digital Reichert AR200 refractometer (Reichert Inc, USA).

All data were subjected to analysis of variance by $5 \% \mathrm{~F}$ test probability. When significant difference was found, the mean test (Tukey at 5\% probability) was used.

\section{RESULTS AND DISCUSSION}

\section{Weather data}

Regarding the meteorological data in the months of April, May and June, higher values of air temperatures were recorded as time progressed (Fig. 1). The minimum, mean and maximum air temperature fluctuated in $15^{\circ} \mathrm{C}$ to $21^{\circ} \mathrm{C}$, $27^{\circ} \mathrm{C}$ to $34^{\circ} \mathrm{C}$ and $41^{\circ} \mathrm{C}$ to $50^{\circ} \mathrm{C}$, respectively, registering high values in June. The relative humidity decreased as days progressed, minimum varied in $18 \%$ to $19 \%$, mean in $47 \%$ to $57 \%$ and maximum in $78 \%$ to $84 \%$, presenting lower values in June (Fig. 2).

\section{Plant growth}

The plant growth and development were favored by grafted condition (Table 2). The height plant, leaves number and leaf area of Centenario variety plant presented higher values $(\mathrm{P} \leq 0.05)$ in grafted condition compared to ungrafted. The rootstocks Forticuke F1 and L. siceraria (Lag 53) presented a significant effect with average height $36.6 \%$ and $26.5 \%$, respectively, greater than ungrafted plant. Leaves number development in all grafted plants increased significantly from $46.0 \%$ to $49.0 \%$. Leaf area was significantly superior in Forticuke F1 rootstock with $19.0 \%$ greater than normal condition, while in materials of L. siceraria (Lag 48 and Lag 53) had an increase between $11.6 \%$ and $10.2 \%$.

Grafting favors a higher biomass of the plant (Alan et al., 2007) due to a greater root development that supplies more water and nutrients even in adverse conditions (Li et al., 2014; Zhu et al., 2008). Consequently, greater concentration of mineral in stem tissues (Colla et al., 2012). At enzymatic level, increased activity has been evidenced in enzymes nitrate reduction, glutamine synthetase and glutamate synthetase in metabolism without nitrogen stimulated by graft under stress conditions (Yang et al., 2013). The above favours availability of soluble amino acids and proteins resulting in greater growth of plants (Pulgar et al., 2000). 
The growth of cucumber plants can be affected by presence of M. incognita (Cuadra et al., 2009) due to obstructions in root that reduce the transport of water and nutrients (Devran et al., 2017; Navarrete et al., 2018). However, incorporation of graft in cucumber production has reduced effects of nematodes as with results obtained in this investigation. Similarly, El-Eslamboly and Deabes (2014) observed that when evaluating Lama Cucumber variety grafted with three $L$. siceraria accessions in nematode infested soils, there were increases in plant height, leaf number and leaf area of $63 \%, 115 \%$, and $26 \%$ greater than ungrafted plants, respectively. However, not all Lagenaria accessions can present favorable responses in nematode control. Ban et al. (2014) found that cucumber variety Adrian grafted with commercial L. siceraria emphasis rootstock showed similar values in stem length when comparing plants without grafting on soil infested with nematodes while the number of leaves was lower.

\section{Fruit quality}

Weight and pulp texture (internal firmness) varied significantly $(\mathrm{P} \leq 0.05)$ by rootstock used in Centenario variety cucumber, subjected to soil infested with root-knot nematodes (Table 3). Forticuke F1 rootstock promoted greater weight with respect to normal condition in $23.5 \%$, whereas when using $L$. siceraria accessions Lag 48 and Lag 53 the increases were $14.6 \%$ and $15.2 \%$, respectively. These results in grafted plants are due to slight increases in fruit dimensions, where a positive correlation of weight was found with parameters of length $(\mathrm{P}<0.001)$, diameter $(\mathrm{P}<0.01)$ and internal firmness $(\mathrm{P}<0.05)$ of fruit (Table 4$)$.
Similar increases in weight were found when evaluating Lama variety grafted with different commercial $L$. siceraria rootstocks on soil infested nematodes, where increases were from $23.6 \%$ to $26.3 \%$ more than in fruits from ungrafted plants (El-Eslamboly and Deabes, 2014). While, in varieties Sinai and Lama cucumber grafted with Cucurbita hybrids there were no significant increases (Amin and Mona, 2014; El-Eslamboly and Deabes, 2014).

Development and greater weight of fruits in grafted plants is attributed to root system of rootstock that tolerates incidence of soil nematodes. L. siceraria species used as rootstock in cucumber plant have moderate resistance like other cucurbitaceae species (El-Wanis et al., 2013). Nematode resistance is induced by less amount of root galls, females and egg masses in grafted condition with respect to the nongrafted plant (El-Wanis et al., 2013). This condition makes possible the supply of water and nutrients from root to aerial part of plants expressing greater height, leaves number and leaf area. Another factor associated with development of grafted plants is stimulation of photosynthetic activity, where chlorophyll content in cucumber plants is higher compared to ungrafted condition, being cultivated in soils contaminated with M. incognita (Amin and Mona, 2014).

Internal firmness of fruits increased significantly $56.5 \%$ in plants grafted with Forticuke F1 rootstock with respect to ungrafted plants, while using creole materials of L. siceraria Lag 48 and Lag 53 generated increases of $2.2 \%$ and $12.6 \%$, respectively (Table 3). Variation of firmness in cucumber fruits is associated with calcium content that interacts with

Table 2: Growth parameters of Centenario variety cucumber plant grafted with commercial rootstock and Lagenaria siceraria accessions in soils infested with root-knot nematodes

\begin{tabular}{lcccc}
\hline Variety/rootstock & Height $(\mathbf{c m})$ & Internode distance $(\mathbf{c m})$ & Leaves number & Leaf area $\left(\mathbf{c m}^{2}\right)$ \\
\hline Centenario $(\mathrm{C})$ & $127.01 \pm 5.20^{1} \mathrm{~b}^{2}$ & $11.38 \pm 0.60$ & $11.12 \pm 0.57 \mathrm{~b}$ & $148.95 \pm 7.06 \mathrm{~b}$ \\
C/Lag 48 & $142.05 \pm 2.00 \mathrm{~b}$ & $12.54 \pm 0.29$ & $16.57 \pm 1.02 \mathrm{a}$ & $166.22 \pm 1.99 \mathrm{ab}$ \\
C/Lag 53 & $160.69 \pm 8.17 \mathrm{a}$ & $12.83 \pm 0.83$ & $16.23 \pm 0.75 \mathrm{a}$ & $164.14 \pm 5.48 \mathrm{ab}$ \\
C/Forticuke F1 & $173.53 \pm 2.02 \mathrm{a}$ & $13.11 \pm 0.29$ & $16.54 \pm 1.17 \mathrm{a}$ & $177.27 \pm 1.33 \mathrm{a}$ \\
HSD & 15.12 & 2.74 & 4.52 & 23.14 \\
CV & 3.71 & 8.12 & 11.07 & 5.22 \\
\hline
\end{tabular}

${ }^{1}$ Values as mean \pm SE. ${ }^{2}$ Values followed by same letters in the column do not differ significantly at $\mathrm{P}<0.05$ error level, according to Tukey's HSD (honestly significant difference) test

Table 3: Quality parameters of Centenario variety cucumber fruit grafted with commercial rootstock and Lagenaria siceraria accessions in soils infested with root-knot nematodes

\begin{tabular}{|c|c|c|c|c|c|c|}
\hline Variety/rootstock & Weight (gr) & Length (cm) & Diameter (mm) & $\begin{array}{c}\text { External } \\
\text { firmness (N) }\end{array}$ & $\begin{array}{c}\text { Internal } \\
\text { firmness (N) }\end{array}$ & $\begin{array}{c}\text { Content of } \\
\text { soluble (brix) }\end{array}$ \\
\hline Centenario $(\mathrm{C})$ & $185.50 \pm 03.75^{1} b^{2}$ & $19.77 \pm 1.25$ & $38.60 \pm 3.29$ & $69.97 \pm 4.24$ & $36.17 \pm 4.28 b$ & $5.10 \pm 0.20$ \\
\hline C/Lag 48 & $213.67 \pm 21.67 a b$ & $21.97 \pm 1.27$ & $39.33 \pm 3.49$ & $64.85 \pm 4.69$ & $36.96 \pm 4.47 b$ & $5.90 \pm 0.55$ \\
\hline C/Lag 53 & $212.67 \pm 13.98 \mathrm{ab}$ & $21.13 \pm 1.19$ & $41.13 \pm 1.94$ & $71.03 \pm 3.13$ & $40.74 \pm 5.31 \mathrm{ab}$ & $5.97 \pm 0.27$ \\
\hline C/Forticuke F1 & $232.50 \pm 02.02 \mathrm{a}$ & $21.65 \pm 0.03$ & $45.65 \pm 0.89$ & $73.64 \pm 0.19$ & $56.60 \pm 2.56 \mathrm{a}$ & $6.05 \pm 0.20$ \\
\hline HSD & 45.52 & 3.49 & 10.42 & 17.36 & 18.16 & 1.477 \\
\hline CV & 7.98 & 6.12 & 9.36 & 9.19 & 15.77 & 9.49 \\
\hline
\end{tabular}

${ }^{1}$ Values as mean \pm SE. ${ }^{2}$ Values followed by same letters in the column do not differ significantly at $\mathrm{P}<0.05$ error level, according to Tukey's HSD (honestly significant difference) test 
Table 4: Pearson correlation coefficients among quality parameters of Centenario variety cucumber fruit grafted with commercial rootstock and Lagenaria siceraria accessions in soils infested with root-knot nematodes

\begin{tabular}{lccccc}
\hline & Weight & Length & Diameter & $\begin{array}{c}\text { External } \\
\text { firmness }\end{array}$ & $\begin{array}{c}\text { Internal } \\
\text { firmness }\end{array}$ \\
\hline Length & $0.823^{\star \star * 2}$ & & & & \\
Diameter & $0.802^{* *}$ & $0.760^{\star *}$ & & & \\
$\begin{array}{l}\text { External } \\
\text { firmness }\end{array}$ & $0.315^{\text {ns }}$ & $-0.021^{\text {ns }}$ & $0.502^{\text {ns }}$ & & \\
$\begin{array}{l}\text { Internal } \\
\text { firmness }\end{array}$ & $0.664^{*}$ & $0.413^{\text {ns }}$ & $0.731^{* *}$ & $0.219^{\text {ns }}$ & \\
$\begin{array}{l}\text { Content } \\
\text { of soluble }\end{array}$ & $0.343^{\text {ns1 }}$ & $0.382^{\text {ns }}$ & $0.417^{\text {ns }}$ & $-0.340^{\text {ns }}$ & $0.521^{\text {ns }}$ \\
\hline
\end{tabular}

${ }^{1} \mathrm{~ns}$; non-significant at $\mathrm{P} \leq 0.05$ error level. ${ }^{2 \star} \mathrm{P} \leq 0.05,{ }^{* *} \mathrm{P} \leq 0.01$, ${ }^{* * *} \mathrm{P} \leq 0.001$

pectic acid to form calcium pectate to maintain a rigid cell wall structure (Wei and Zhao, 2020). Wherein, the formation of calcium bridges between pectic polymers are responsible for cell adhesion and tissue integrity of cucumber mesocarp tissue (Sajnin et al., 2003). An increase in calcium content is a favorable effect of rootstock that induces greater assimilation, despite incidence of nematodes. Calcium quantifications in foliage of cucumber plants grafted with L. siceraria showed an increase of $29.6 \%$ and $45.0 \%$ in first and second cultivation cycle developed in nematode infested soils (El-Wanis et al., 2013).

\section{CONCLUSION}

Forticuke F1 (Numhems ${ }^{\circledR}$ ) and Lag 53 (Mexican L. siceraria accession) rootstocks favored the plant height, number of leaves and leaf area and weight and firmness of the fruit in soils infested with M. incognita. Lag 53 is a promising source for developing new rootstock cultivars.

\section{ACKNOWLEDGMENTS}

The authors are grateful to the Autonomous University of Baja California for the support granted through the third Internal Call for Special Research Projects.

\section{Author contributions}

A. M. Suárez, O. Grimaldo. Research project planning and design. Prepared the first draft of the manuscript and revised the final version. C. Ceceña, F. Núnez, D. Gonzalez. Analysis and interpretation of the results obtained. All authors performed the literature search, edited the draft and approved the final version.

\section{REFERENCES}

Alan, O., N. Zdemir and Y. Nen. 2007. Effect of grafting on watermelon plant growth, yield and quality. J. Agron. 6: 362-365.
Amin, A. W. and A. W. Mona. 2014. Protecting cucumber from Meloidogyne incognita using graft onto resistant cucurbit rootstocks and antagonistic marigold as an alternative to nematicide. Pak. J. Nematol. 32: 51-58.

Ban, S. G., K. Žanić, G. Dumičić, E. Raspudić, G. V. Selak and D. Ban. 2014. Growth and yield of grafted cucumbers in soil infested with root-knot nematodes. Chil. J. Agric. Res. 74: 29-34.

Cadahia, C. 2005. Fertirrigación: Cultivos Hortícolas, Frutales y Ornamentales. Mundi-Prensa, Madrid, España.

Colla, G., Y. Rouphael, E. Rea and M. Cardarelli. 2012. Grafting cucumber plants enhance tolerance to sodium chloride and sulfate salinization. Sci. Hortic. 135: 177-185.

Cuadra, R., J. Ortega, L. Soto and M. A. Zayas-Vázquez. 2009. Efecto del dazomet en el control de nematodos agalleros en la producción de pepino en condiciones de cultivo protegido. Rev. Prot. Veg. 24: 57-61.

Del Prado-Vera, I. C., A. Tovar-Soto y J. A. Hernández. 2001. Distribución de especies y razas de Meloidogyne en México. Rev. Mex. Fitopatol. 19: 32-39.

Devran, Z., I. Mistanoglu and T. Ozalp. 2017. Occurrence of mixed populations of root-knot nematodes in vegetable greenhouses in Turkey, as determined by PCR screening. J. Plant Prot. Res. 124: $617-630$

El-Eslamboly, A. A. S. A. and A. A. A. Deabes. 2014. Grafting cucumber onto some rootstocks for controlling root- knot nematodes. Minufiya J. Agric. Res. 39: 1109-1129.

Elsheery, N. I., M. N. Helaly, A. O. Samar, V. S. J. Sunoj, M. Zabochnicka-Swiatek, H. M. Kalaji and A. Rastogi. 2020. Physiological and molecular mechanisms of salinity tolerance in grafted cucumber. S. Afr. J. Bot. 130: 90-102.

El-Wanis, M. M., A. W. Amin and G. A. R. Tomader. 2013. Evaluation of some cucurbitaceous rootstocks 2-effect of cucumber grafting using some rootstocks on growth, yield and its relation with root-knot nematode Meloidogyne incognita and Fusarium wilt, infection. Egypt. J. Agric. Res. 91: 235-257.

Grimaldo, O., A. M. Suárez, C. Ceceña and D. González. 2018. Diversidad morfológica de semilla y fruto de diez colectas mexicanas de Lagenaria siceraria. Agron. Mesoam. 29: 63-74.

Gupta, R. C., I. R. Miller Mukherjee, R. B. Doss, J. K. Malik and D. Milatovic. 2017. Organophosphates and carbamates. In R. C. Gupta (Ed.), Reproductive and Developmental Toxicology. Vol. 2. Academic Press, London, UK, pp. 609-631.

Huang, Y., R. Tang, Q. Cao and Z. Bie. 2009. Improving the fruit yield and quality of cucumber by grafting onto the salt tolerant rootstock under $\mathrm{NaCl}$ stress. Sci. Hortic. 122: 26-31.

Jones, J. G., N. M. Kleczewski, J. Desaeger and S. F. L. Meyer. 2016. Evaluation of nematicides for Southern root-knot nematode management in lima bean. Crop Prot. 96: 151-157.

Levi, A., J. Thies, K. Ling, A. Simmons, C. Kousik and R. Hassell. 2009. Genetic diversity among Lagenaria siceraria accessions containing resistance to root-knot nematodes, whiteflies, ZYMV or powdery mildew. Plant Genet. Resour. 7: 216-226.

Li, J., F. Zhang, D. Fang, Z. Li, M. Gao, H. Wang and D. Wu. 2014 Effects of water and nitrogen supply on the growth and water use efficiency of cucumber (Cucumis sativus L.) under fertigation. Sci. Agric. Sin. 47: 4475-4487.

Maroto, J. V., I. Borrego, A. Miguel y F. Pomares. 2002. El Cultivo de la Sandía. Mundi-Prensa, Cuidad de México, México.

MMXFF023. 1983. Productos Alimenticios no Industrializados para uso Humano-fruta Fresca-pepino-(Cuccumis sativus)especificaciones. Secretaria del Comercio y Fomento Industrial, Norma Mexicana, México. 
Navarrete, X., L. Ron, P. Viteri and W. Viera. 2018. Parasitism of the root knot nematode Meloidogyne incognita (Kofoid and White) Chitwood in five wild Solanaceae species. Rev. Fac. Nac. Agron. Medellín. 71: 8367-8373.

Noor, R. S., Z. Wang, M. Umair, M. Yaseen, M. Ameen, S. U. Rehman, M. U. Khan, M. Imran, W. Ahmed and Y. Sun. 2019. Interactive effects of grafting techniques and scion-rootstocks combinations on vegetative growth, yield and quality of cucumber (Cucumis sativus L.). Agronomy 9: 288.

Pulgar, G., G. Villora, D. A. Moreno and L. Romero. 2000. Improving the mineral nutrition in grafted watermelon plants: Nitrogen metabolism. Biol. Plant. 43: 607-609.

Punithaveni, V., P. Jansirani and M. Sivakumar. 2015. Screening of cucurbitaceous rootstocks and cucumber scions for root knot nematode resistance (Meloidogyne incognita Kofoid and White). Electron. J. Plant Breed. 6: 486-492.

Sajnin, C., G. Gamba, L. N. Gerschenson and A. M. Rojas. 2003. Textural, histological and biochemical changes in cucumber (Cucumis sativus L.) due to immersion and variations in turgor pressure. J. Sci. Food Agric. 83: 731-740.

Singh, R. and S. Phulera. 2015. Plant parasitic nematodes: The hidden enemies of farmers. In: S. Yadav and R. Singh (Eds.), Environmental Issues for Socio-Ecological Development. Excel
India Publishers, New Delhi, India, pp. 68-81.

Suárez, A. M., O. Grimaldo, A. M. García, D. González and M. V. Huitrón. 2017b. Influence of rootstock on postharvest watermelon quality. Rev. Chapingo Ser. Hortic. 23: 49-58.

Suárez, A. M., O. Grimaldo, A. M. García, D. González and M. V. Huitrón. 2017a. Evaluación de portainjertos criollos de Lagenaria siceraria en la producción de sandía injertada. Idesia (Chile). 35 : 39-44.

Thangamani, C., L. Pugalendhi and V. Punithaveni. 2018. Screening wild and cultivated cucurbits against root-knot nematode to exploit as rootstocks for grafting in cucumber. J. Hortic. Sci. 13: 32-41.

Wei, D. and X. Zhao. 2020. Calcium maintained higher quality and enhanced resistance against chilling stress by regulating enzymes in reactive oxygen and biofilm metabolism of Chinese winter jujube fruit. J. Food Biochem. 44: e13161.

Yang, Y., X. Lu, B. Yan, B. Li, J. Sun, S. Guo and T. Tezuka. 2013. Bottle gourd rootstock-grafting affects nitrogen metabolism in $\mathrm{NaCl}$-stressed watermelon leaves and enhances short-term salt tolerance. J. Plant Physiol. 170: 653-661.

Zhu, J., Z. Bie, Y. Huang and X. Han. 2008. Effect of grafting on the growth and ion concentrations of cucumber seedlings under $\mathrm{NaCl}$ stress. J. Plant. Nutr. Soil Sci. 54: 895-902. 